\title{
Case Report: Disorder of Sex Development 46, XY with Proximal Hypospadias in a 10-Year-Old Twin Boy: Disorder of Sex Development 46, XY with Proximal Hypospadias
}

\author{
Androniko Setiawan $^{1} \quad$ Andrian $^{1} \quad$ Tjahjo Djojo Tanojo $^{2} \quad$ Rina Yudiwati $^{3}$ \\ 1.Participant of the Andrology 1 Specialist Doctor Education Program, Faculty of Medicine, Airlangga \\ University/ RSUDDr. Soetomo, Surabaya, Indonesia \\ 2.SMF of Andrology, RSUD Dr Soetomo, Surabaya, Indonesia \\ 3.Department of Medical Biology, Faculty of Medicine, Airlangga University, Indonesia
}

\begin{abstract}
Hypospadias is a congenital defect in which the opening of the urethra is located on the ventral side of the penis proximal to the tip of the glans penis. The cause of hypospadias is still not clear and believed to have several factors. Hypospadias occurs due to disruption of urethral fold fusion at the $8^{\text {th }}-15^{\text {th }}$ week in the uterus which is influenced by dihydrotestosterone. Hypospadias can cause a disorder of sex development according to the conditions. A case of proximal hypospadias was reported to occur in a 10-year-old twin boy accompanied by undescended testis causing a disorder of sex development. For this case, various examinations were carried out along with evaluations to establish the diagnosis, the cause, the treatment plan, and the necessary evaluation.
\end{abstract}

Keywords: hypospadias, disorder of sex development, undescended testis

DOI: $10.7176 / \mathrm{JHMN} / 80-01$

Publication date:September $30^{\text {th }} 2020$

\section{Introduction}

Hypospadias is a congenital defect in which the opening of the urethra is located on the ventral side of the penis proximal to the tip of the glans penis. The urethral meatus can be located in glandular to perineal. ${ }^{1-3}$ The incidence rate of hypospadias is 1 of 300 live births. ${ }^{2,4-6}$ The risk of recurrent hypospadias in the first offspring is 13 times greater, and that in twins is $50 \%{ }^{4-6}$ The age of the mother at pregnancy also greatly influence the occurrence of hypospadias. ${ }^{7}$ However, the exact cause of hypospadias is still unknown. Some patients with hypospadias have abnormalities such as the abnormal production of testosterone by the testis and adrenal glands, failure to convert testosterone to dihydrotestosterone, androgen receptor disorders, and genetic disorders. 2,8 Environmental exposure factors, both from food, drugs, and chemicals have the role of risk factors for hypospadias. ${ }^{9-11}$

Sexual differentiation and development of the urethra begins in the uterus at the $8^{\text {th }}$ week and ends at the $15^{\text {th }}$. At this stage, the virilization process occurs, influenced by the testosterone hormone. The testosterone hormone at this age is produced as a result of stimulation by placental hCG. ${ }^{12}$ The urethra is formed from urethral fold fusion along the ventral surface from the penis to the corona from the distal part. The urethra is formed from canalization of the ectodermal cord extending through the glands so that it can unite with the fused urethral fold. ${ }^{12}$ Hypospadias, based on the location, can be classified into three, namely glanular (located in the glanular), distal (located in the sub-coronal, distal penile, and mid-shaft), and proximal (located in the proximal penile, penoscrotal, scrotal, and perineal) ${ }^{13}$. Hypospadias types can be divided into two, namely isolated and syndromic. Approximately $90 \%$ of cases of hypospadias are of an isolated type. ${ }^{4,6}$ Patients with development delay, dysmorphic facial features, and/ or anorectal malformations are suspected of having syndromic-type hypospadias. ${ }^{14}$ Management of hypospadias requires investigations to find the cause, as well as operative actions for repair. Hypospadias in patients with a male phenotype, especially in those suspected of having a disorder of sex development (DSD) accompanied with an undescended testis, a karyotyping test can be performed. Supporting examinations for imaging in the form of intravenous pyelography and voiding cystourethrography is not needed because it is not an indication of isolated hypospadias regardless of degree. ${ }^{14}$

In patients with hypospadias, it is necessary to perform operative action to repair the hypospadias by monitoring and evaluate the outcome in the form of urinary, sexual, and cosmetic functions. Hypospadias repair operative action can be performed at the age of 3 months or more. ${ }^{14}$

\section{Case Report}

A 10-year-old boy came with his parents to the Outpatient Installation Andrology Polyclinic of the Regional General Hospital (RSUD) Dr Soetomo in January 2018 mainly complaining downward urinary spray because the urethra was not at the tip of the penis from birth. The patient was referred from the Urology Clinic for Andrology Clinic.

According to the parents, the child is a twin (Gemelli) and their first offspring. It took around 39 years-old 
pregnancy. During the pregnancy, there was no consumption of drugs and exposure to dangerous chemicals, but the mother had fallen three times in a sitting position and had premature rupture of the membranes. The child (patient) was born by sectio caesaria (SC) at the gestational age of 8 months. The patient was the second-born twin with a birth weight of 1,800 gram and a body length of $45 \mathrm{~cm}$. The period of development of the patient in the motor and sensory fields was within the normal limit and there were no complaints or other diseases. The parents denied that the same disease ran in the family. Based on the examination carried out, the patient's identical twin was identified to have distal hypospadias (sub corona). From the family status, the patient's father was the first of five children in his family while the patient's mother is the fourth of ninth children in her family. Both parents of the patient have an identical twin sister (aunt). The patient does not have problems in the school, family and neighborhood life.

Physical examination of the patient showed a pulse of $90 \mathrm{x} /$ minute and nutritional status of obesity with a height of $142 \mathrm{~cm}$, bodyweight of $64 \mathrm{~kg}$, body mass index of 31.7, an abdominal circumference of $99 \mathrm{~cm}$, and a hand length of $144 \mathrm{~cm}$. General physical examination of the head, thoracic, abdominal, inguinal and extremities was all normal. Secondary sexual signs had not been obtained, the patient was still in Tanner stage 1.

In the external genitalia examination, there was no pubic hair found. Moreover, there was a phallus resembling a penis with proximal hypospadias located in the penoscrotal with a bifid scrotum. It was difficult to evaluate from the internal genitalia examination for the testis, vas deferens, and epididymis.
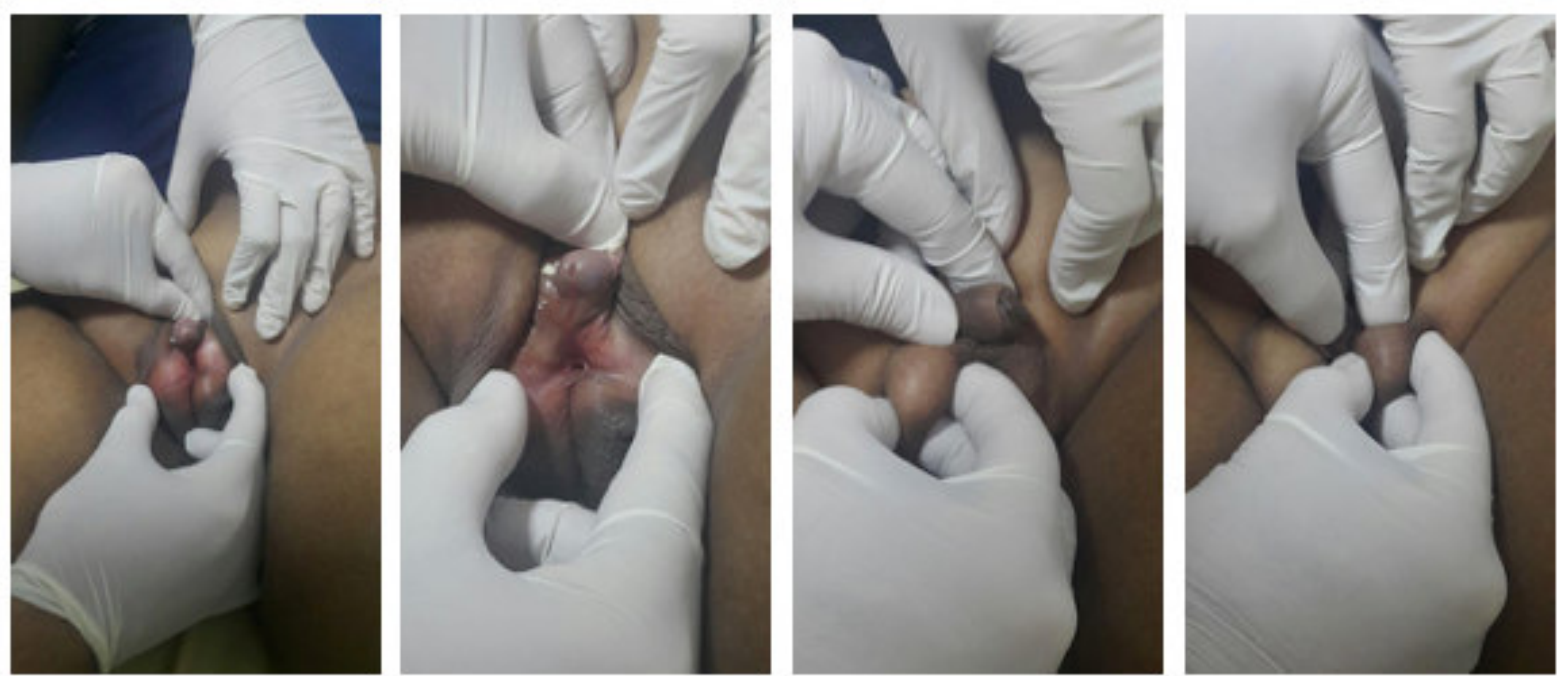

Figure 1. Physical Examination Results of Penoscrotal Hypospadias and Scrotum Bifidum

The patient had experienced a testicular ultrasound examination from which a bilateral ectopic undescended testis was identified with a smaller right testis size than the left testis and an impression that the volume was still within normal limits at the age of 10 years.

The patient was subjected to hormonal laboratory examinations in the form of estradiol, LH, FSH, and testosterone continued with a karyotyping test. The laboratory test showed results that were still within normal limits, namely estradiol of $27.96 \mathrm{pg} / \mathrm{ml}$, LH of $0.37 \mathrm{mIU} / \mathrm{mL}, \mathrm{FSH}$ of $5.95 \mathrm{mIU} / \mathrm{ml}$, and testosterone of 24.92 $\mathrm{ng} / \mathrm{dl}$. A karyotyping test of peripheral blood was performed and resulted in $46, \mathrm{XY}$. 


\section{RESULTS OF CHROMOSOME ANALYSIS}

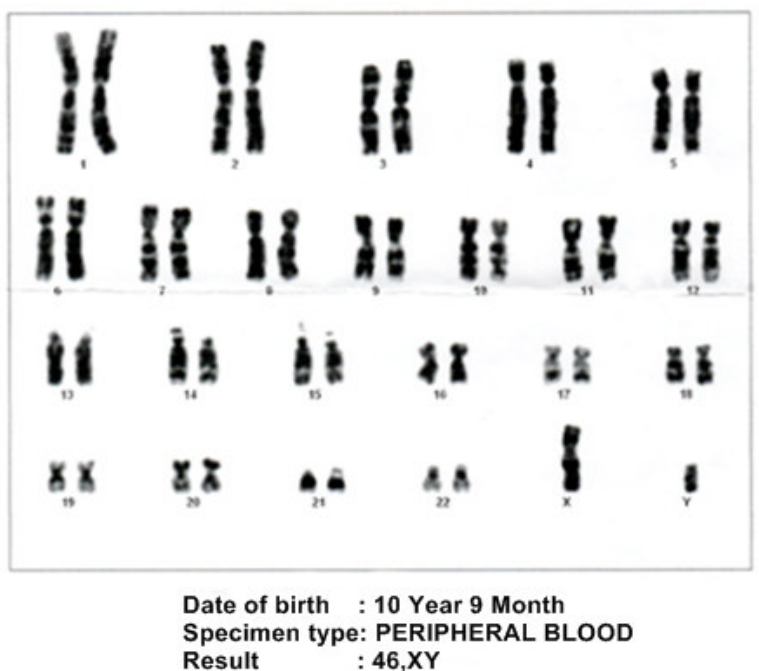

Figure 2. Results of Karyotyping test

Based on the anamnesis results, the physical examination, accompanied by previous supporting tests, the patient was diagnosed with a disorder of sex development 46, XY with proximal hypospadias (penoscrotal), scrotum bifida, and bilateral undescended testicle. The patient was planned to undergo surgery for further treatment by being referred back to the urology department. Counseling, information, and education are given to patients regarding the need for lifestyle modification based on the nutritional status of obesity. Further genetic testing is needed to determine the cause. Also, it is necessary to take further follow-up, especially regarding capabilities in reproductive function at reproductive age.

\section{Discussion}

The main complaint of hypospadias case reports is consistent with the definition of hypospadias where the opening of the urethra is not located at the tip of the penis but is located on the ventral side of the penis proximal to the tip of the glans penis. ${ }^{1,2,15}$ For the complaint of downward urinary spray, it will adjust the position of the opening of the urethra according to the classification. The history of the mother's age at pregnancy and the condition were also said to influence the risk of developing hypospadias. ${ }^{16}$ In the patient's twin sibling, the presence of hypospadias was also found, supporting the study stating the risk of developing hypospadias in identical twins. ${ }^{5,6,17}$

The findings of physical examination in the case report can confirm the diagnosis of hypospadias, especially by classification based on the location of entry into the proximal hypospadias because it is located in the penoscrotal. ${ }^{1,13,14}$ The presence of undescended testis was in the bilateral supra-ectopic in the $8-15^{\text {th }}$ week, same as the embryological course of the cause of hypospadias. ${ }^{12,18}$ The supporting laboratory examinations obtained results that were still within normal limits, but could not provide a complete picture of the cause. The USG examination also supports the existence of undescended testis, leading to a proximal hypospadias case. This case is a disorder of sex development and it is necessary to perform a karyotyping test. The karyotyping test obtained normal results of $46, \mathrm{XY}$. In the hypospadias case, it is necessary to know the data in the form of dihydrotestosterone levels, genetic testing for the 5-alpha-reductase enzyme and androgen receptors. ${ }^{2,8,12}$ The limitation, in this case, is that no additional information about the patient's twin sibling is provided.

The management for this case is an operative action in the form hypospadias orchidopexy and repair which will be performed in the urology department. In one literature, it is stated that the preoperative androgen stimulation therapy option to increase the size of the penile and enlarge the circumference of the glans penis. ${ }^{14}$ The therapy is still considered to be controversial from the two previous studies, resulting in complications of urethroplasty. A study suggested that a significant reduction based on urethroplasty complications and another study showed a continuously increasing complication from enlarged glans with stimulation, compared to those of the same size without stimulation. ${ }^{14}$ In this case, education is very needed on lifestyle modification to improve nutritional status, the need for further genetic examination to find the cause, and the need for follow-up regarding its urinary, sexual, and cosmetic functions. In this case, a further follow-up is needed regarding the capabilities of the reproductive function.

\section{Conclusion}

Hypospadias is a case that emphasizes diagnosis establishment through physical examination, but requires further investigation, especially in finding the cause. Hypospadias has different classifications and variances that 
can cause a disorder of sex development and requires quite complex management and further evaluation.

\section{References}

1. B Purnomo B. Dasar-dasar Urologi. 3rd ed. Jakarta: Saung Seto; 2014. 382 p.

2. Leung AKC, Robson WLM. Hypospadias: an update. Asian J Androl. 2007;9:16-22.

3. McAninch JW, Lue TF. Smith \& Tanagho's general urology. [Internet]. 2020 [cited 2020 Sep 2]. Available from: https://accessmedicine.mhmedical.com/book.aspx?bookid=2840

4. Calzolari E, Contiero MR, Roncarati E, Mattiuz PL, Volpato S. Aetiological factors in hypospadias. J Med Genet. 1986;23:333-7.

5. Schnack TH, Zdravkovic S, Myrup C, Westergaard T, Christensen K, Wohlfahrt J, et al. Familial Aggregation of Hypospadias: A Cohort Study. Am J Epidemiol. 2007;167:251-6.

6. Stoll C, Alembik Y, Roth MP, Dott B. Genetic and environmental factors in hypospadias. :5.

7. Fisch H, Golden RJ, Libersen GL, Hyun GS, Madsen P, New MI, et al. Maternal age as a risk factor for hypospadias. J Urol. 2001;165:934-6.

8. Baskin LS, Ebbers MB. Hypospadias: anatomy, etiology, and technique. J Pediatr Surg. 2006;41:463-72.

9. Bouty A, Ayers KL, Pask A, Heloury Y, Sinclair AH. The Genetic and Environmental Factors Underlying Hypospadias. Sex Dev. 2015;9:239-59.

10. Skakkebaek NE, Jørgensen N, Andersson A-M, Juul A, Main KM, Jensen TK, et al. Populations, decreasing fertility, and reproductive health. The Lancet. 2019;393:1500-1.

11. Winston JJ, Meyer RE, Emch ME. Geographic analysis of individual and environmental risk factors for hypospadias births: GEOGRAPHIC ANALYSIS OF HYPOSPADIAS RISK FACTORS. Birt Defects Res A Clin Mol Teratol. 2014;100:887-94.

12. Hutson JM, Warne GL, Grover SR, editors. Disorders of sex development: an integrated approach to management. Heidelberg; New York: Springer; 2012. 311 p.

13. Hadidi AT, Azmy AF, editors. Hypospadias Surgery [Internet]. Berlin, Heidelberg: Springer Berlin Heidelberg; 2004 [cited 2018 May 13]. Available from: http://link.springer.com/10.1007/978-3-662-078419

14. Wein AJ, Kavoussi LR, Partin AW, Peter CA. CAMPBELL-WALSH UROLOGY, ELEVENTH EDITION. :4903.

15. Tanagho EA, McAninch JW. Smith's General Urology. :770.

16. Fisch H, Golden RJ, Libersen GL, Hyun GS, Madsen P, New MI, et al. MATERNAL AGE AS A RISK FACTOR FOR HYPOSPADIAS. :3.

17. van der Horst HJR, de Wall LL. Hypospadias, all there is to know. Eur J Pediatr. 2017;176:435-41.

18. Rodprasert W, Virtanen HE, Mäkelä J-A, Toppari J. Hypogonadism and Cryptorchidism. Front Endocrinol [Internet]. $2020 \quad$ [cited $2020 \quad$ Sep $\quad 2] ; 10 . \quad$ Available from: https://www.frontiersin.org/article/10.3389/fendo.2019.00906/full 